\title{
Surveillance of Nosocomial Infections in a Private Hospital with Particular Emphasis on Characterization and Drug Resistance Pattern
}

\author{
D. B. Phule* and A. V. Manwar \\ Department of Microbiology, Dnyanopasak College of Arts, Commerce, Science, and \\ Technology, College Parbhani Maharashtra, India \\ *Corresponding author
}

\section{A B S T R A C T}

\begin{tabular}{|l|}
\hline Ke y w o r d s \\
Nosocomial \\
infection, \\
Surveillance, \\
Antibiotic \\
sensitivity, \\
Minimum inhibitory \\
concentration \\
\hline Article Info \\
\hline $\begin{array}{l}\text { Accepted: } \\
\text { 20 December } 2020 \\
\text { Available Online: } \\
\text { 10 January 2021 }\end{array}$ \\
\hline
\end{tabular}

\section{Keywords}

Nosocomial

Minimum inhibitory
Nosocomial Infections (NIs) surveillance plays a vital role in reduced infection rates. Numbers of hospitals are practising the same for many years, and positive effects have demonstrated. Therefore, this study also attempted to evaluate the tendency of NIs towards drug resistance and the resultant impact of surveillance on NIs rates and advisory as a precautionary measure. The use of selective nutrient media assisted in isolating nosocomial pathogens under NIs surveillance program. The Nosocomial pathogens identified by $16 \mathrm{~S}$ rRNA and $18 \mathrm{~S}$ rRNA gene sequencing and tested for antibiogram and MIC assay to note the antibiotic sensitivity pattern. The private hospital's different sections found to be positive for nosocomial pathogens identified as $E$. coli, $K$. pneumoniae, S. aureus, E. faceium, P. aeruginosa and fungi Candida albicans. Further based on the antibiogram, all strains found to be multidrug-resistant with an increased MIC level making them virulent strains as per NIs surveillance program carried out in hospital of Maharashtra, India. As per NIs surveillance program carried out in hospital of India, pathogens showcased heterogenicity of prevalence as per areas, and further remained multidrug-resistant even to the third-generation drug indicated the controlling action against them is prerequisite and reported accordingly to the ethical committee monitoring the study.

\section{Introduction}

The hospitals are committed to giving the best of the facility to the patient's, but they are now experiencing the growing challenge of nosocomial infection (NI). NIs can hinder the progress of the patient's recovery further can prolong hospital stay and can increase the economic burden of both patients and hospitals. The length of stay due to NIs reported to increase by 9.1 days with ventilator-associated pneumonia (VAP), and by 9.5 days in case of central line-associated bloodstream infection (Mehta et al., 2016). Besides, as per estimated cost, additional expenditure increases by 4900 Euro for per hospital-acquired bloodstream infection (Vrijeus et al., 2010). As early as in 1983, it was proven once that surgical wound surveillance could reduce surgical site 
infections (Condon et al., 1983), now many publications focusing on the role of surveillance systems. In one study, for prevention of NIs, ten key points were mentioned; one of them is surveillance and feedback (Zingg et al., 2015). The main points involved in surveillance were to collect information about the outbreak and to give comparable data for benchmarking potential spread.

Till date, the number of countries succeeded in establishing their national or regional surveillance system, by involving network and electronic records to transfer data fast (Woeltje et al., 2011; Inacio et al., 2011). Take the cognizance of the NIs surveillance, the number of hospitals is implementing the same for many years, and their impact needs to be explored. Therefore, the aim of this study to evaluate the present status of NIs in a private hospital, India about drug resistance pattern showcased by them.

\section{Materials and Methods}

\section{Site of sampling}

The incidences of multidrug-resistant human pathogens are on the rise and mainly prevalent in hospital settings that demand regular surveillance. In the study one of the private hospitals of Parbhani, Maharashtra considered for registering the drug resistance in bacterial and fungal species prevalent in hospital settings.

During sampling, swab samples collected from the bed, saline stands, ventilators, doors, patient's blood and wound. The swab then transferred to the normal saline and processed for microbial isolation of selective media.

\section{Growth of isolates on selective media}

The presence of Escherichia coli, Staphylococcus aureus, Enterobacter aerogenes, Klebsiella pneumoniae and Pseudomonas aeruginosa in hospital environment confirmed by inoculation on the Hichrome agar, MacConkey agar, Blood agar, Eosin methylene blue agar, Mannitol salt agar, and Cystine-lactose-electrolyte deficient medium by incubating at $37^{\circ}$ for 24 hours. Isolates further purified and identified as per $16 \mathrm{~S}$ rRNA gene sequencing.

\section{S rRNA gene sequencing}

Preliminary identified nosocomial pathogens identified by $16 \mathrm{~S}$ rRNA gene sequence information, once its homology recorded with nucleotide database available with NCBI as per protocol suggested by Rai et al., (2013).

\section{S rRNA gene sequencing}

Fungal isolate also targeted for $18 \mathrm{~S}$ rRNA gene locus by using universal primers: Forward primer ITS1 TCCGTAGGTGA ACCTGCGG and Reverse primer ITS2 TCCTCCGCTTATTGATATGC by setting up PCR conditions as Initial denaturation at $94^{\circ} \mathrm{C}$ for 2 minutes, amplification for 35 cycles with set conditions as $94^{\circ} \mathrm{C}$ for $45 \mathrm{sec}$, $55^{\circ} \mathrm{C}$ for $60 \mathrm{sec}$, and $72^{\circ} \mathrm{C}$ for $60 \mathrm{sec}$. Lastly extension made at $72^{\circ} \mathrm{C}$ for 10 minutes. Amplicon then sequenced and checked for close homology via phylogeny.

\section{Antibiotic sensitivity assay}

We identified nosocomial bacterial pathogens once tested for antibiotic sensitivity against 14 antibiotics by involving standard KirbyBauer disc diffusion assay. Those named as ampicillin, cefoperazone, ceftriaxone, nalidixic acid, ciprofloxacin, tetracycline, erythromycin, trimethoprim, ofloxacin, vancomycin, amikacin, gentamicin, levofloxacin and chloramphenicol.

Similarly, fungal isolate also been checked for antibiotic sensitivity against variconazole, 
caspofungin, fluconazole, ketoconazole, and itraconazole.

The bacterial plates incubated at $37^{\circ} \mathrm{C}$ while fungal plates at $28^{\circ} \mathrm{C}$ for $24 \mathrm{~h}$ and $96 \mathrm{~h}$, respectively. The formed zone of inhibition noted for prevalent sensitivity as per CLSI and EUCAST standard and isolates noted for their drug sensitivity.

\section{Minimum inhibitory concentration assay}

The antibiotics representing resistance against nosocomial pathogens tested further for MIC as per the protocol of Palomino et al., (2002).

\section{Results and Discussion}

\section{Identification of nosocomial pathogens}

The prevalence of nosocomial pathogens in the hospital setting recorded once the growth of $E$. coli, $K$. pneumoniae, $S$. aureus, $E$. aerogenes, $P$. aeruginosa and fungi $C$. albicans noted on the selective media tested. The colony characteristics and typical growthbased identity then confirmed by $16 \mathrm{~S}$ rRNA and 18S rRNA gene sequence homology.
As per 16S rRNA gene sequencing isolate DP1 with $99.2 \%$ homology identified as $E$. coli (Acc. No. MN0063) (Fig. 1a).

Isolate DP02 registered $100 \%$ sequence homology with Klebsiella pneumoniae (Acc. No. MN00638.1) as in Fig. 1b.

Isolate DP03 recorded 99.63\% homology with 16S rRNA gene of Staphylococcus aureus (Acc. No. CP053183.1) as in Fig. 1c.

Isolated DP04 recorded $100 \%$ sequence identity with $16 \mathrm{~S}$ rRNA gene of Enterococcus faecium (Acc. No. MK990044.1) as in Fig. $1 \mathrm{~d}$.

Isolate DP05 with $100 \%$ sequence match recorded homology with Pseudomonas aeruginosa (Acc. No. MN006381.1) as noted in Fig. 1e.

As per 18S rRNA gene sequencing isolate DP06 marked 100\% homology with Candida albicans (Acc. No. MK998696.1) and identified as $C$. albicans as in Fig. 1f.

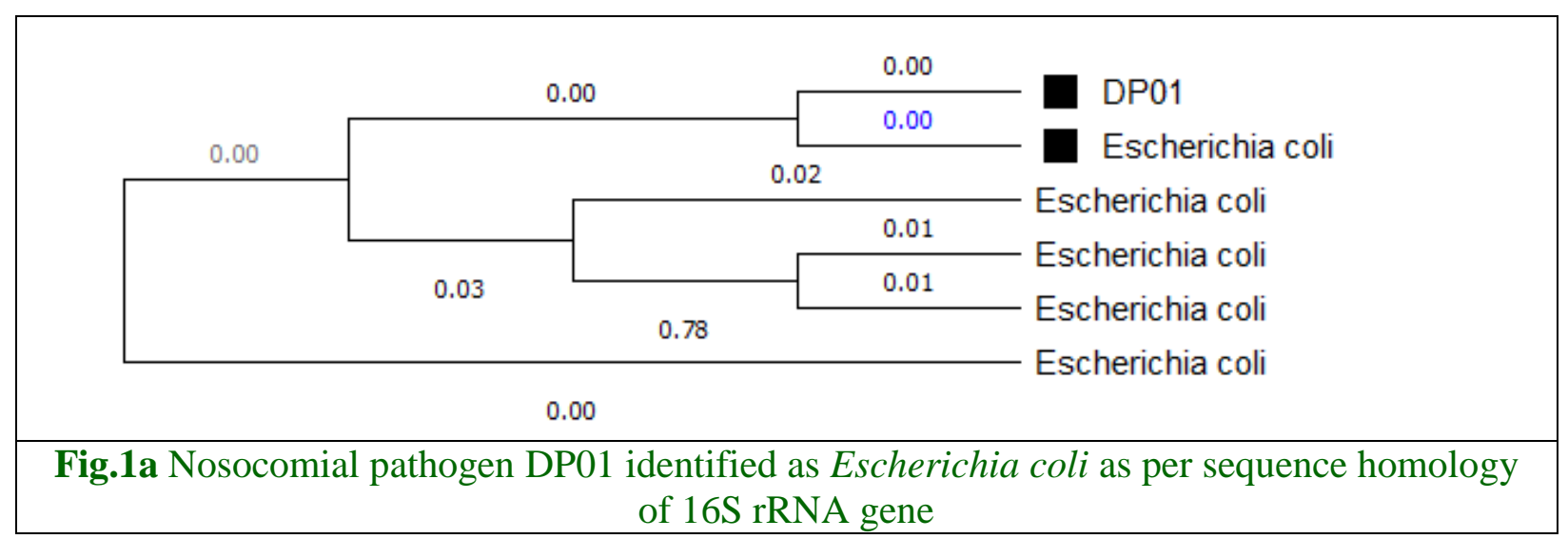




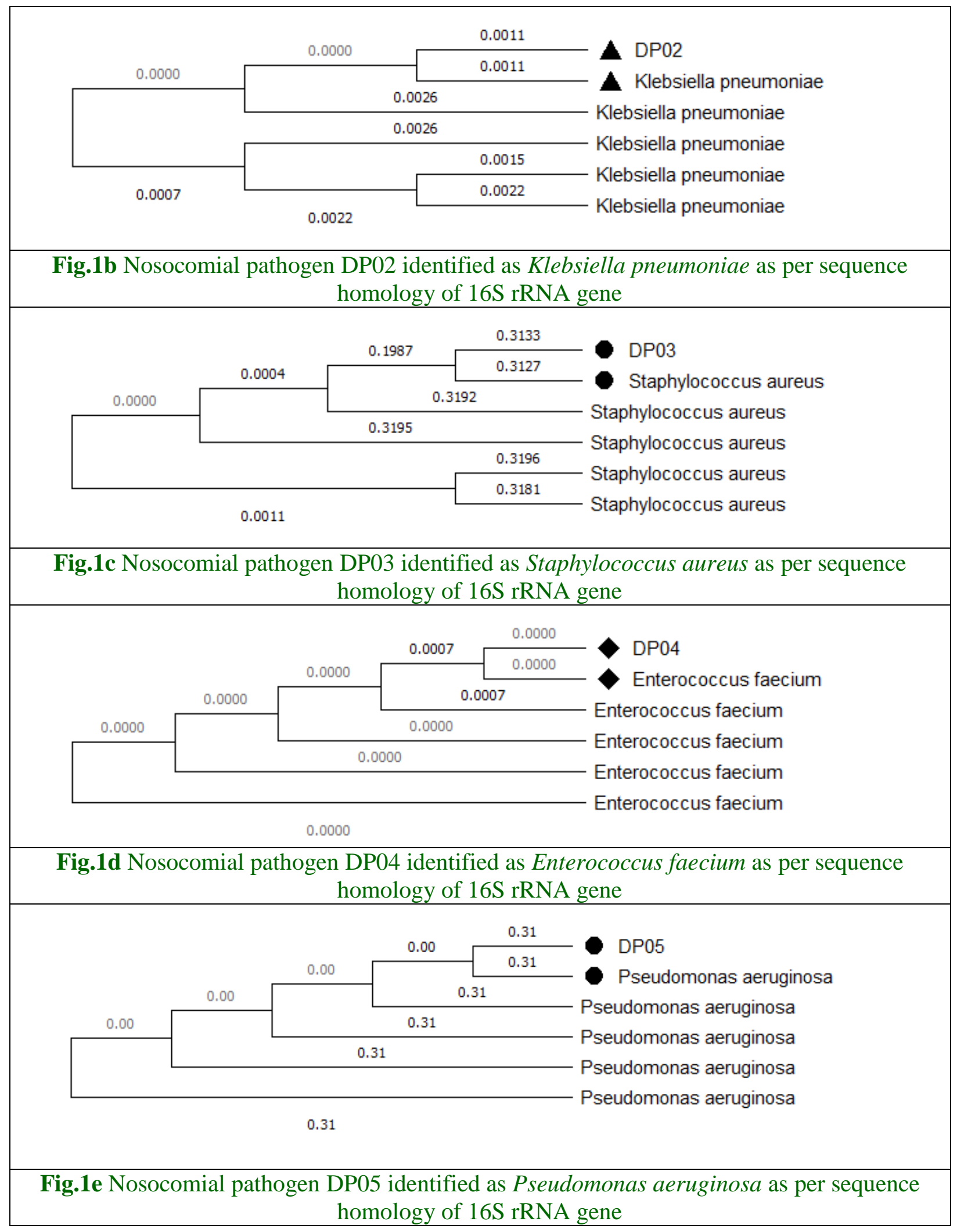




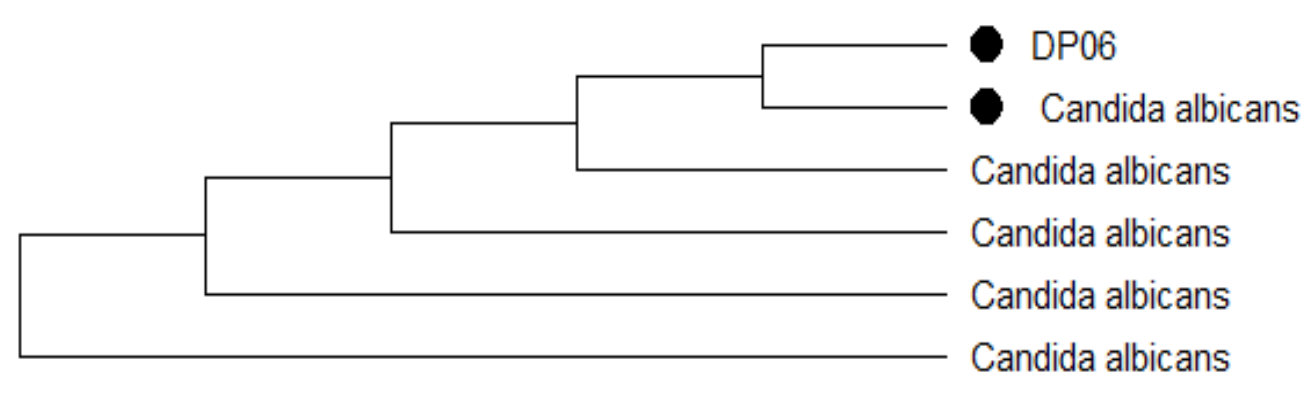

Fig.1f Nosocomial pathogen DP06 identified as Candida albicans as per sequence homology of 18S rRNA gene

\section{Antibiotic sensitivity assay}

Once identified by $16 \mathrm{~S}$ rRNA and $18 \mathrm{~S}$ rRNA gene sequencing nosocomial pathogens checked for antibiotic sensitivity as per drug class.

\section{Ampicillin}

Ampicillin sensitivity recorded with E. coli, $S$. aureus, $E$. aerogenes but found to be resistance with $K$. pneumoniae and $P$. aeruginosa (Table 1).

\section{Cefoperazone}

Nosocomial pathogens namely $E$. coli, $K$. pneumoniae, E. aerogenes and $P$. aeruginosa recorded to be resistant towards cefoperazone which is worrisome (Table 1).

\section{Ceftriaxone}

With antibiotic ceftriaxone increased resistance recorded with $K$. pneumoniae, $E$. aerogenes and $P$. aeruginosa (Table 1).

\section{Nalidixic acid}

Three nosocomial pathogens found to be resistance towards nalidixic acid namely $K$. pneumoniae, P. aeruginosa and S. Aureus
(Table 1).

\section{Ciprofloxacin}

The only resistance recorded with $P$. aeruginosa for the drug ciprofloxacin (Table $1)$.

\section{Tetracycline}

Tetracycline resistance noted with $K$. pneumoniae and E. aerogenes only (Table 1).

\section{Erythromycin}

As per CLSI standard, erythromycin registered resistance in $E$. coli, $K$. pneumoniae, E. aerogenes and $P$. aeruginosa (Table 1).

\section{Trimethoprim}

The most resistance against trimethoprim noted with $P$. aeruginosa, $K$. pneumoniae and S. aureus (Table 1).

\section{Ofloxacin}

The antibiotic resistance towards ofloxacin noted with $K$. pneumonia, E. aerogenes and $P$. aeruginosa (Table 1). 


\section{Vancomycin}

As a worrisome factor even, vancomycin recorded resistance with four nosocomial pathogens namely E. coli, K. pneumoniae, E. aerogenes and $P$. aeruginosa (Table 1$)$.

\section{Amikacin}

In a relief point of view, all five nosocomial pathogens remained sensitive towards amikacin (Table 1).

\section{Gentamicin}

The commonly used gentamicin also noted with resistance by $K$. pneumoniae, $E$. aerogenes and $P$. aeruginosa and others as sensitive (Table 1).

\section{Levofloxacin}

The only resistance recorded with $P$. aeruginosa and others as sensitive (Table 1).

\section{Chloramphenicol}

The isolates namely $K$. pneumonia and $E$. aeruginosa noted to be resistance towards chloramphenicol (Table 1).

The overall study reported the major drugresistant features with nosocomial pathogens and demanded regular screening in hospitals.

\section{MIC of standard antibiotics}

Based on the antibiotic sensitive assay, nosocomial bacterial as well as fungal species found to be multidrug resistance in features. It is essential to understand the MIC level of those.

\section{E. coli strain DP1}

E. coli increasing antibiotic MIC noted with ofloxacin, levofloxacin, cefoperazone, cefotaxime, ceftriaxone $(1.56 \mu \mathrm{g} / \mathrm{ml}) \quad>$ gentamycin $12.5 \mu \mathrm{g} / \mathrm{ml}>$ and amikacin $(50$ $\mu \mathrm{g} / \mathrm{ml})$. Hence drugs with MIC of $1.56 \mu \mathrm{g} / \mathrm{ml}$ are a better performer (Table 3 and Fig. 2).

\section{K. pneumoniae strain DP2}

The best-scored MIC recorded with ofloxacin, levofloxacin, cefotaxime, ceftriaxone $(1.56 \mu \mathrm{g} / \mathrm{ml})$ followed by amikacin, cefoperazone, and gentamycin $(50 \mu \mathrm{g} / \mathrm{ml})$ (Table 3 and Fig. 2).

\section{S. aureus DP3}

The better MIC recorded with ofloxacin, levofloxacin, cefoperazone, cefotaxime, ceftriaxone $(1.56 \mu \mathrm{g} / \mathrm{ml})$ followed by gentamycin $(12.5 \mu \mathrm{g} / \mathrm{ml})$ and amikacin $(25$ $\mu \mathrm{g} / \mathrm{ml}$ ) (Table 3and Fig. 2).

\section{E. aerogenes DP4}

The best MIC values for antibiotics recorded as levofloxacin $(1.25 \mu \mathrm{g} / \mathrm{ml})$, ofloxacin $(3.15$ $\mu \mathrm{g} / \mathrm{ml})$, cefotaxime $(6.25 \mu \mathrm{g} / \mathrm{ml})$, ceftriaxone $(6.25 \mu \mathrm{g} / \mathrm{ml})$, cefoperazone (12 $\mu \mathrm{g} / \mathrm{ml})$, amikacin $(25 \mu \mathrm{g} / \mathrm{ml})$ and gentamycin $(25$ $\mu \mathrm{g} / \mathrm{ml})$. Hence use of levofloxacin can be recommended (Table 3and Fig. 2).

\section{P. aeruginosa DP5}

$P$. aeruginosa noted with best MIC value with levofloxacin $(3.12 \mu \mathrm{g} / \mathrm{ml})$, then cefoperazone $(3.12 \mu \mathrm{g} / \mathrm{ml})$ and cefotaxime $(6.25 \mu \mathrm{g} / \mathrm{ml}) ;$. At the same time, other drugs failed to give precise MIC values (Table 3and Fig. 2).

In a common point, MIC values for vancomycin, amphotericin and kanamycin not prominently recorded with any nosocomial pathogens.

\section{C. albicans DP6}

The nosocomial fungal pathogen $C$. albicans DP6 noted for best MIC values with 
voriconazole $(6.25 \mu \mathrm{g} / \mathrm{ml})$ and fluconazole $(6.25 \mu \mathrm{g} / \mathrm{ml})$ followed by caspofungin and ketoconazole $(12.5 \mu \mathrm{g} / \mathrm{ml})$. Thereby, high
MIC noted with Itraconazole $(50 \mu \mathrm{g} / \mathrm{ml})$ as in Table 4.

Table.1 Antibiotic sensitivity pattern of nosocomial bacterial pathogens as per CLSI and EUCAST standard

\begin{tabular}{|c|c|c|c|c|c|c|}
\hline Sr. No. & Name of & \multicolumn{5}{|c|}{ Zone of Inhibition (mm) } \\
\hline & Antibiotics & DP1 & DP2 & DP3 & DP4 & DP5 \\
\hline 1 & Ampicillin & $21 \pm 1$ & - & $35 \pm 1$ & $18 \pm 2$ & $10 \pm 2$ \\
\hline 2 & Cefoperazone & $29 \pm 1$ & $10 \pm 3$ & $28 \pm 1$ & $15 \pm 2$ & $17 \pm 2$ \\
\hline 3 & Ceftriaxone & $30 \pm 1$ & $13 \pm 3$ & $25 \pm 1$ & $21 \pm 2$ & $12 \pm 3$ \\
\hline 4 & Nalidixic acid & $22 \pm 2$ & $13 \pm 1$ & $12 \pm 1$ & $12 \pm 2$ & - \\
\hline 5 & Ciprofloxacin & $31 \pm 2$ & $21 \pm 1$ & $26 \pm 1$ & $21 \pm 1$ & - \\
\hline 6 & Tetracycline & $20 \pm 1$ & $10 \pm 1$ & $28 \pm 1$ & $10 \pm 1$ & $30 \pm 1$ \\
\hline 7 & Erythomycin & $16 \pm 2$ & $11 \pm 1$ & $27 \pm 2$ & $12 \pm 2$ & $15 \pm 1$ \\
\hline 8 & Trimethoprim & $22 \pm 1$ & $17 \pm 1$ & $22 \pm 2$ & $27 \pm 2$ & - \\
\hline 9 & Ofloxacin & $25 \pm 2$ & $18 \pm 2$ & $24 \pm 1$ & $17 \pm 2$ & - \\
\hline 10 & Vancomycin & - & - & $15 \pm 1$ & - & - \\
\hline 11 & Amikacin & $22 \pm 1$ & $18 \pm 2$ & $20 \pm 1$ & $19 \pm 1$ & $19 \pm 1$ \\
\hline 12 & Gentamicin & $20 \pm 2$ & $13 \pm 1$ & $20 \pm 1$ & $12 \pm 1$ & - \\
\hline 13 & Levofloxacin & $26 \pm 2$ & $18 \pm 1$ & $25 \pm 1$ & $20 \pm 2$ & - \\
\hline 14 & chloramphenicol & $22 \pm 2$ & $15 \pm 1$ & $23 \pm 2$ & $11 \pm 2$ & $23 \pm 1$ \\
\hline \multicolumn{7}{|c|}{ Values in triplicate; \pm zone deviation in mm; - No zone obtained } \\
\hline DP1 Escherichia coli, DP2 Klebsiella pneumoniae, DP3 Staphylococcus aureus, DP4 \\
\hline \multicolumn{7}{|c|}{ Enterobacter aerogenes, DP5 Pseudomonas aeruginosa } \\
\hline
\end{tabular}

Table.2 Antibiotic sensitivity pattern of nosocomial fungal pathogens as per CLSI and EUCAST standard

\begin{tabular}{|c|c|c|}
\hline Sr.No. & Name of Antibiotics & Zone of Inhibition (mm) \\
\cline { 3 - 3 } & & C. albicans DP6 \\
\hline 11 & Variconazole & $24 \pm 2$ \\
\hline 12 & Caspofungin & $19 \pm 2$ \\
\hline 13 & Fluconazole & $21 \pm 3$ \\
\hline 14 & Ketaconazole & $13 \pm 2$ \\
\hline 15 & Intraconazole & - \\
\hline & Values in triplicate; \pm zone deviation in $\mathrm{mm} ;-$ No zone obtained \\
\hline
\end{tabular}


Table.3 MIC assay of Standard drugs against Nosocomial pathogens

\begin{tabular}{|c|c|c|c|c|c|c|}
\hline \multirow[t]{2}{*}{ Sr.No. } & \multirow[t]{2}{*}{ Name of Antibiotics } & \multicolumn{5}{|c|}{ Minimum Inhibitory Concentration in $\mu \mathrm{g} / \mathrm{ml}$} \\
\hline & & DP1 & DP2 & DP3 & DP4 & DP5 \\
\hline 1 & $\begin{array}{l}\text { Ofloxacin } \\
2 \mathrm{mg} / \mathrm{ml}\end{array}$ & 1.56 & 1.56 & 1.56 & 3.15 & - \\
\hline 2 & $\begin{array}{l}\text { Amikacin } \\
125 \mathrm{mg} / \mathrm{ml}\end{array}$ & 50 & 50 & 25 & 25 & - \\
\hline 3 & $\begin{array}{c}\text { Levofloxacin } \\
100 \mathrm{mg} / \mathrm{ml}\end{array}$ & 1.56 & 1.56 & 1.56 & 1.56 & 3.12 \\
\hline 4 & $\begin{array}{c}\text { Cefoperazone } \\
100 \mathrm{mg} / \mathrm{ml}\end{array}$ & 1.56 & 50 & 1.56 & 12. & 3.12 \\
\hline 5 & $\begin{array}{l}\text { Cefotaxime } \\
100 \mathrm{mg} / \mathrm{ml}\end{array}$ & 1.56 & 1.56 & 1.56 & 6.25 & 6.25 \\
\hline 6 & $\begin{array}{c}\text { Vancomycin } \\
100 \mathrm{mg} / \mathrm{ml}\end{array}$ & - & - & - & - & - \\
\hline 7 & $\begin{array}{c}\text { Amphotericin } \\
100 \mathrm{mg} / \mathrm{ml}\end{array}$ & - & - & - & - & - \\
\hline 8 & $\begin{array}{c}\text { Kanamycin } \\
100 \mathrm{mg} / \mathrm{ml}\end{array}$ & - & - & - & - & - \\
\hline 9 & $\begin{array}{c}\text { Ceftriaxone } \\
100 \mathrm{mg} / \mathrm{ml}\end{array}$ & 1.56 & 1.56 & 1.56 & 6.25 & 12.5 \\
\hline 10 & $\begin{array}{c}\text { Gentamycin } \\
25 \mathrm{mg} / \mathrm{ml}\end{array}$ & 12.5 & 50 & 12.5 & 25 & - \\
\hline
\end{tabular}

Table.4 MIC assay of Antifungal drugs against $C$. albicans

\begin{tabular}{|c|c|c|}
\hline Sr. No. & Name of Antibiotics & $\begin{array}{c}\text { Minimum Inhibitory Concentration in } \\
\boldsymbol{\mu g} / \mathbf{m l}\end{array}$ \\
\hline 1 & $\begin{array}{c}\text { Variconazole } \\
100 \mathrm{mg} / \mathrm{ml}\end{array}$ & 6.25 \\
\hline 2 & $\begin{array}{c}\text { Caspofungin } \\
100 \mathrm{mg} / \mathrm{ml}\end{array}$ & 12.5 \\
\hline 3 & $\begin{array}{c}\text { Fluconazole } \\
2 \mathrm{mg} / \mathrm{ml}\end{array}$ & 6.25 \\
\hline 4 & $\begin{array}{c}\text { Intrconazole } \\
10 \mathrm{mg} / \mathrm{ml}\end{array}$ & 50 \\
\hline 5 & $\begin{array}{c}\text { Ketaconazole } \\
100 \mathrm{mg} / \mathrm{ml}\end{array}$ & 12.5 \\
\hline
\end{tabular}




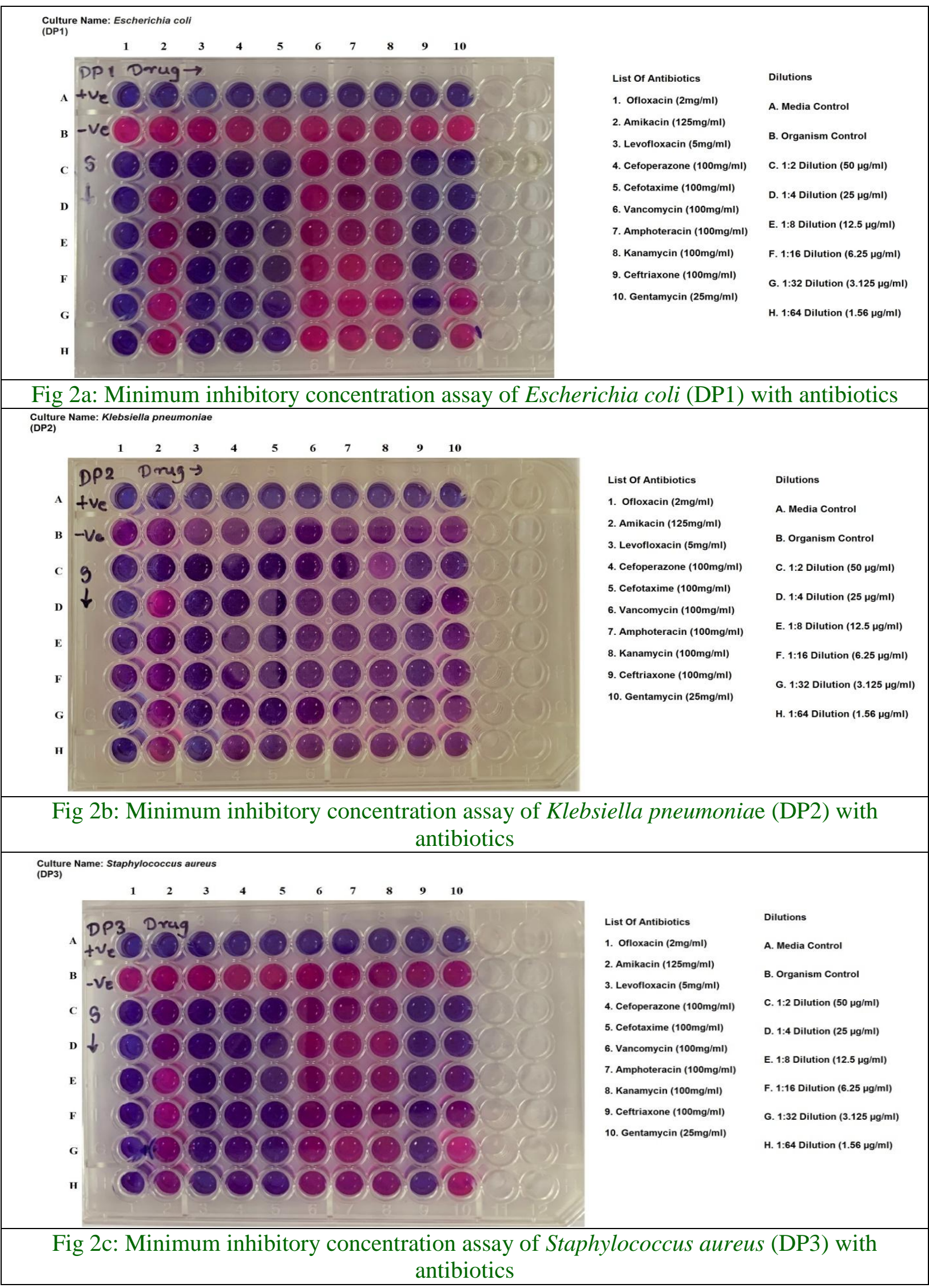




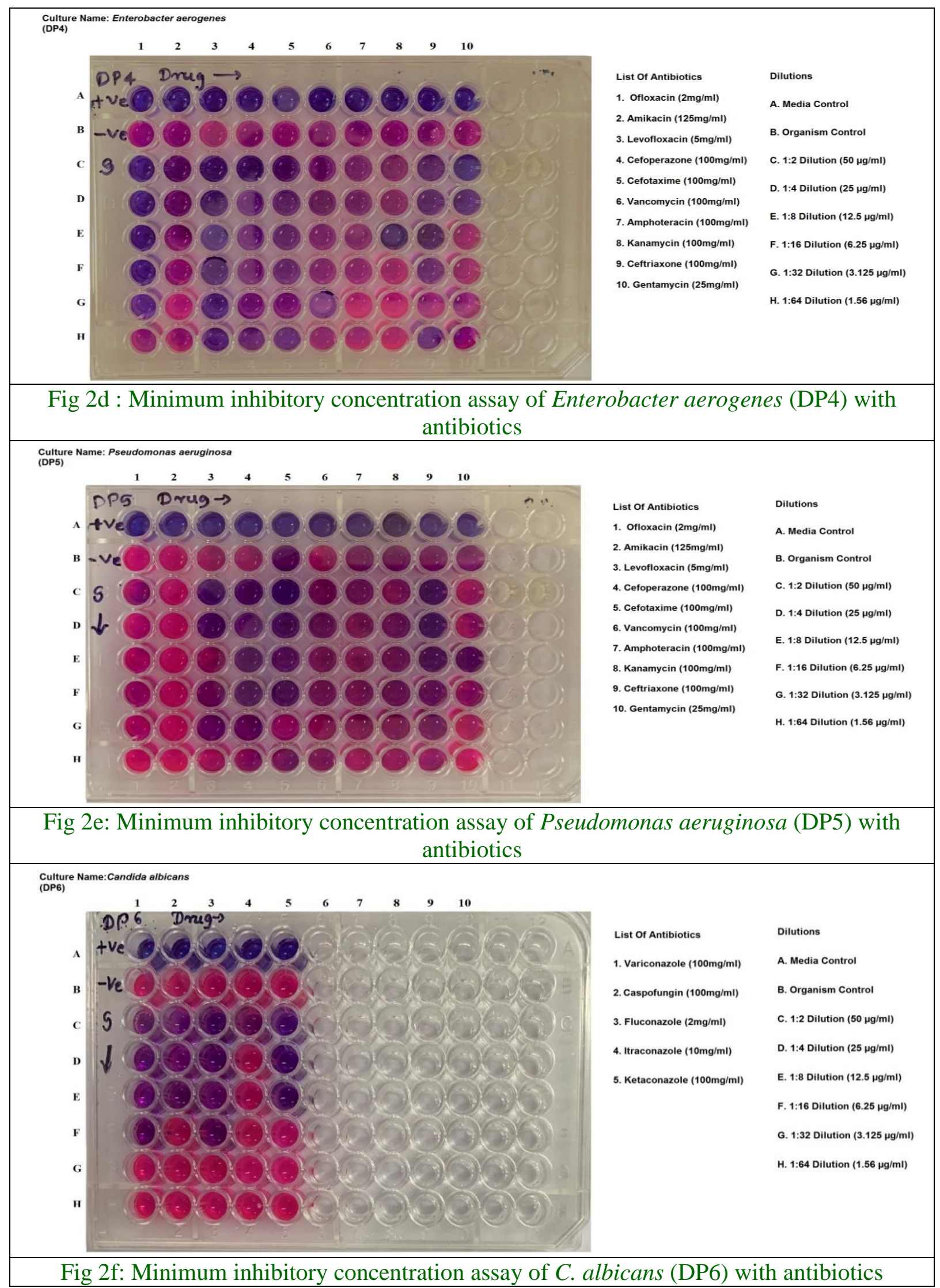


The widespread of multidrug-resistant nosocomial pathogens in hospital settings reported in India; hence putting up an added burden for proper treatment by increasing the processes of screening, more extended hospital stay and increased economic burden (Yadav et al., 2016; Mehta et al., 2016; Jaggi et al., 2013). In the present study, a private hospital of Parbhani situated in Maharashtra, India reported having an infection of nosocomial pathogens especially of $E$. coli, $K$. pneumoniae, S. aureus, E. faecium and $P$. aeruginosaas bacterial species. Further fungi species identified as Candida albicans as nosocomial pathogens. We found some strains possessed multidrug-resistant features once noted by antibiotic sensitivity assay. The study also recorded an increased MIC level to control better these pathogens, which is worrisome as per antibiotic therapy is concerned in earlier reports of multidrug resistance nosocomial pathogens very well reported in India. Pachori et al., (2019) isolated MDR $P$. aeruginosa in intensive care unit; MRSA S. aureus (Kale and Dhawan, 2016); E. coli (Shaik et al., 2017); E. aerogenes (Loiwal et al., 1999), and Carbapenem-resistant $K$. pneumoniae (Veeraraghavan et al., 2017). The study also noted that third-generation vancomycin resistance was also on a higher side, especially in the ICU and hospital ward samples mainly with E. coli, K. pneumoniae, $E$. aerogenes and $P$. aeruginosa. The drug resistance towards vancomycin by the Enterococci hence reported with chances of community hospital outbreaks (Beltrami et $a l ., 2000)$. The presence of VRSA and MRSA is also the common picture during hospital surveillance and putting up a series question about its use for treatment (Smith, 1999).

In the present study, isolated C. albicans, fortunately, reported sensitive towards voriconazole, caspofungin, and fluconazole but strong resistance recorded towards
Intraconazole and Ketoconazole. Earlier $C$. albicans resistance recorded prominently against intraconazole (Feng et al., 2016; Giamarellos-Bourboulis et al., 2019; Zida et al., 2017). Ketoconazole resistance noted earlier in C. albicans in Indian clinical isolates (Mane et al., 2016). About 22.9\% of strains of $C$. albicans reported ketoconazole resistance in Ouagadougou and linked to be showcase possibility of community transmissions.

In conclusion, as per the present study, it has come to fore that hospital in India need to screen regularly for the prevalence status of nosocomial infection so that community transmission could be avoided and better treatment could ensure by establishing permanent surveillance body as multidrug resistant nosocomial pathogens were prevalent in the hospital screened.

\section{References}

Beltrami EM, Singer DA, Fish L, et al.. Risk factors for acquisition of vancomycinresistant enterococci among patients on a renal ward during a community hospital outbreak. Am J Infect Control. 2000;28(4):

282-285.

doi:10.1067/mic.2000.106276

Condon R.E., Schulte W.J., Malangoni M.A. and Anderson-Teschendorf M.J. (1983). Effectiveness of a surgical wound surveillance program Arch. Surg., 118, 303-307.

Feng W, Yang J, Pan Y, Xi Z, Qiao Z, Ma Y. (2016). The correlation of virulence, pathogenicity, and itraconazole resistance with SAP activity in Candida albicans strains. Can J Microbiol. 62(2), 173-178.

Giamarellos-Bourboulis EJ, Stamou A, Maraki S, (2019). Susceptibility profiles and clinical efficacy of antifungals against candida bloodstream isolates 
from critically ill patients: Focus on intravenous itraconazole. Int $J$ Antimicrob Agents. 54(4), 471-477.

Inacio, M. C., Paxton, E. W., Chen, Y., Harris, J., Eck, E., Barnes, S., and Ake, C. F. (2011). Leveraging electronic medical records for surveillance of surgical site infection in a total joint replacement population. Infection Control \& Hospital Epidemiology, 32(4), 351-359.

Jaggi N, Rodrigues C, Rosenthal VD, (2013). Impact of an international nosocomial infection control consortium multidimensional approach on central line-associated bloodstream infection rates in adult intensive care units in eight cities in India. Int $J$ Infect Dis. 17(12), 1218-1224

Kale P, Dhawan B. (2016). The changing face of community-acquired methicillinresistant Staphylococcus aureus. Indian J Med Microbiol. 34(3), 275-285.

Loiwal V, Kumar A, Gupta P, Gomber S, Ramachandran VG. (1999).

Enterobacter aerogenes outbreak in a neonatal intensive care unit. Pediatr Int. 1999;41(2):157-161.

Mane A, Vidhate P, Kusro C, et al., Molecular mechanisms associated with Fluconazole resistance in clinical Candida albicans isolates from India. Mycoses. 2016; 59(2): 93-100.

Mehta Y, Jaggi N, Rosenthal VD., (2016). Device-Associated Infection Rates in 20 Cities of India, Data Summary for 2004-2013: Findings of the International Nosocomial Infection Control Consortium. Infect Control Hosp Epidemiol. 37(2),172-181.

Pachori P, Gothalwal R, Gandhi P. (2019). Emergence of antibiotic resistance Pseudomonas aeruginosa in intensive care unit; a critical review. Genes Dis. 6(2), 109-119.

Palomino, J. C., Martin, A., Camacho, M.,
Guerra, H., Swings, J., and Portaels, F. (2002). Resazurin microtiter assay plate: simple and inexpensive method for detection of drug resistance in Mycobacterium tuberculosis. Antimicrobial agents and chemotherapy, 46(8), 2720-2722.

Rai, M. M., Gore, D. G., Rathod, M. K., and Khurad, A. M. (2013). Evidence of transovarial transmission of Bacillus subtilis in the silkworm, Bombyx mori L. Journal of Pharmacy Research, 7(4), 318-323.

Shaik S, Ranjan A, Tiwari SK, (2017). Comparative Genomic Analysis of Globally Dominant ST131 Clone with Other Epidemiologically Successful Extraintestinal Pathogenic Escherichia coli (ExPEC) Lineages. mBio.8(5):01596-17.

Smith DW.(1999). Decreased antimicrobial resistance after changes in antibiotic use. Pharmacotherapy. 19(8),129S$137 \mathrm{~S}$.

Veeraraghavan B, Shankar C, Karunasree S, Kumari S, Ravi R, Ralph R. (2017). Carbapenem resistant Klebsiella pneumoniae isolated from bloodstream infection: Indian experience. Pathog Glob Health. 111(5), 240-246.

Vrijens, F. Hulstaert, F. Van de Sande S., Devriese S, Morales I and Parmentier Y. (2010). Hospital-acquired, laboratory-confirmed bloodstream infections: linking national surveillance data to clinical and financial hospital data to estimate increased length of stay and healthcare costs J. Hosp. Infect., 75, $158-162$

Woeltje, K. F., McMullen, K. M., Butler, A. M., Goris, A. J., and Doherty, J. A. (2011). Electronic surveillance for healthcare-associated central lineassociated bloodstream infections outside the intensive care unit.

Y. Mehta, N. Jaggi, V.D. Rosenthal, M. 
Kavathekar, A. Sakle, N. Munshi, M. Chakravarthy, S.K. Todi, N. Saini, C. (2016). Rodrigues et al., Deviceassociated infection rates in 20 cities of India, data summary for 2004-2013: findings of the international nosocomial infection control consortium Infect. Control Hosp. Epidemiol., (37),172181.

Yadav PD, Patil DY, Shete AM, (2016). Nosocomial infection of $\mathrm{CCHF}$ among health care workers in Rajasthan, India. BMC Infect Dis. 16(1), 624.

Zida A, Yacouba A, Bamba S, (2017). In vitro susceptibility of Candida albicans clinical isolates to eight antifungal agents in Ouagadougou (Burkina Faso). J Mycol Med., 27(4), 469-475.

Zingg W., Holmes A., Dettenkofer M., Goetting T., Secci F., Clack L., Allegranzi B., Magiorakos A.P. and Pittet D., (2015). Hospital organisation, management, and structure for prevention of health-care-associated infection: a systematic review and expert consensus Lancet Infect. Dis., (15), 212-224.

\section{How to cite this article:}

Phule, D. B. and Manwar, A. V. 2021. Surveillance of Nosocomial Infections in a Private Hospital with Particular Emphasis on Characterization and Drug Resistance Pattern. Int.J.Curr.Microbiol.App.Sci. 10(01): 3409-3413. doi: https://doi.org/10.20546/ijcmas.2021.1001.401 